\title{
Studies of Immune Functions of Patients with Chronic Hepatitis
}

\author{
Akitaka Nonomura, Mikio Tanino, Hiroshi Kurumaya, \\ Goroku Ohta, Yasuhiro Kato* and Kenichi Kobayashi* \\ Department of Pathology and *Department of Internal \\ Medicine, School of Medicine, Kanazawa University, \\ Kanazawa 920
}

\begin{abstract}
Nonomura, A., Tanino, M., Kurumaya, H., Ohta, G., Kato, Y. and Koвayashi, K. Studies of Immune Functions of Patients with Chronic Hepatitis. Tohoku J. exp. Med., 1982, 137 (2), 163-177— Peripheral T cells from patients with chronic active hepatitis (CAH) showed a significantly decreased suppressor effect (or increased helper effect) on allogeneic B cell differentiation into Ig-producing cells $(\mathrm{Ig}-\mathrm{PC})(p<0.05)$. After irradiation of $\mathrm{T}$ cells to eliminate suppressor influences, mean spontaneous helper activity of CAH was not different from that of healthy subjects, indicating that spontaneous helper activity of $\mathrm{CAH}$ was normal. Concanavalin A (Con A)-induced suppressor cell activity was significantly decreased in $\mathrm{CAH}(p<0.01,9$ defective cases out of 18 patients). Minor defect of Con A-induced suppressor activity was also found in some patients with chronic persistent hepatitis $(\mathrm{CPH})$ ( 2 defective cases out of 14 patients). Autologous mixed lymphocyte reaction (AMLR) was significantly decreased in patients with CAH $(p<0.005)$. Spontaneous suppressor or Con Ainduced suppressor activity was not different statistically between HBsAgpositive and HBsAg-negative cases. Finally, we demonstrated a presence of a serum factor(s) that can decrease Con A-induced suppressor cell function of healthy subjects in 7 of 21 patients with $\mathrm{CAH}$ and 2 of $14 \mathrm{CPH}$. Our results suggest that defective suppressor cell function likely attributable to serum factor(s) may reflect altered immune responses of CAH. - ... suppressor cell; helper cell; autologous MLR; CAH
\end{abstract}

In some patients with chronic active hepatitis (CAH), circulating autoantibodies to smooth muscles, nuclei and mitochondria are occasionally present in their sera, and these are considered to represent a triad of makers of the autoimmune process associated with continuing liver injury (Doniach and Walker 1969). Using various in vitro tests of cellular immunity, lymphocytes from patients with $\mathrm{CAH}$ have been shown to be sensitized to liver antigens (Tobias et al. 1967; Bacon et al. 1972; Miller et al. 1972; Smith et al. 1972; Meyer zum Büschenfelde et al. 1974; Lee et al. 1975), and to be directly cytotoxic to autologous hepatocytes (Paronetto and Vernace 1975; Wands and Isselbacher 1975; Geubel et al. 1976; Vergani et al. 1979), and it has been suggested that these cell-mediated autoimmunities play a role in pathogenesis of $\mathrm{CAH}$. In addition, the presence of antibodies to hepatocyte-surface membrane antigens in sera from patients with CAH (Tage-Jensen et al. 1977; Jensen et al. 1978; Kakumu et al. 1979; Kawanishi and MacDermott 1979) and on

Received for publication, August 22, 1981. 
hepatocytes obtained from CAH patients (Hopf et al. 1975, 1976; Alberti et al. 1976) has led to speculation that a humoral autoimmune mechanism also may participate in the pathogenesis of CAH.

Recent experimental data showed that both $\mathrm{T}$ cells and $\mathrm{B}$ cells capable of reacting with many self-antigens are present even in the healthy subjects and waiting to be triggered (Rose 1978). A maintenance of immunological homeostasis regulated by suppressor and helper $\mathrm{T}$ cell function is considered to be one of the regulatory mechanisms to prevent autoimmune responses (Gershon 1974; Dutton 1975; Rose 1978). Abnormality in the function of suppressor $\mathrm{T}$ cells has been reported in systemic lupus erythematosus (SLE) (Abdou et al. 1976; Bresnihan and Jasin 1977; Horowitz et al. 1977), ulcerative colitis and Crohn's disease (Hodgson et al. 1978) and in juvenile rheumatoid arthritis (Strelkauskas et al. 1978). The association between the decreased suppressor $\mathrm{T}$ cell function and the presence of serum inhibitory factor has been documented in SLE (Sagawa and Abdou 1979) and in juvenile rheumatoid arthritis (Strelkauskas et al. 1978). Decreased suppressor $\mathrm{T}$ cell function was also postulated in development of CAH (Eddleston and Williams 1974). Recently, autologous mixed lymphocyte reaction (AMLR), in which human $\mathrm{T}$ cells respond with increased DNA synthesis to mitomycin-C treated or $\mathrm{x}$-irradiated non- $\mathrm{T}$ cells, is employed to investigate the immunoregulatory function of T cells (Kuntz et al. 1976; Sakane et al. 1978). AMLR was found to be decreased in SLE (Sakane et al. 1978) and in Sjögren's syndrome (Miyasaka et al. 1980).

The purpose of the present investigation is to obtain more precise knowledge of immunoregulatory function in patients with $\mathrm{CAH}$. In the first series of experiments we investigated the suppressor or helper cell activity in patients with $\mathrm{CAH}$ by measuring (a) the capacity of peripheral $\mathrm{T}$ cells or irradiated $\mathrm{T}$ cells to help differentiation of $\mathrm{B}$ cells into plasma cells, and (b) the capacity of $\mathrm{T}$ cells precultured with Concanavalin A (Con A) to suppress differentiation of B cells into plasma cells or to suppress the blast transformation responses of fresh allogeneic lymphocytes. In the second, we tested CAH sera for their ability to inhibit suppressor cell activity of normal human lymphocytes. Finally, we also employed AMLR to study the immunoregulatory function in $\mathrm{CAH}$.

\section{Materials and Methods}

\section{Patients}

The study was performed on 91 patients with chronic hepatitis without clinical or morphological evidence of alcohol abuse, ingestion of known hepatotoxic medication, primary biliary cirrhosis and Wilson's disease. Chronic hepatitis was classified into chronic active hepatitis $(\mathrm{CAH})$ and chronic persistent hepatitis $(\mathrm{CPH})$ according to its morphological pattern based upon Fogarty's histological criteria (Chalmers et al. 1974). Fifty-one patients were classified as CAH and 40 as CPH. Among those with CAH, 31 cases were positive in serum for hepatitis B surface antigen (HBsAg) (26 males and 5 females, mean serum glutamic-oxaloacetic transaminase (SGOT) 84.6 \pm 66.4 (mean \pm s.D.) IU/liter), 3 were positive for anti-HBs (1 male and 2 females, mean SGOT 76.0 \pm 36.1 IU/liter) and 17 were negative for both $\mathrm{HBsAg}$ and anti-HBs (12 males and 5 females, mean 
SGOT $89.8 \pm 59.2 \mathrm{IU} /$ liter). In these subgroups of CAH, SGOT levels were not statistically different. Nine patients with $\mathrm{CPH}$ were positive for $\mathrm{HBsAg}(8$ males and 1 female, mean SGOT 48.5 \pm 13.9 IU/liter), 6 were positive for anti-HBs (3 males and 3 females, mean SGOT $53.4 \pm 22.3 \mathrm{IU} /$ liter) and 25 were negative for both $\mathrm{HBsAg}$ and anti-HBs (21 males and 4 females, mean SGOT $34.9 \pm 23.0 \mathrm{IU} /$ liter). In these subgroups of CPH, SGOT levels were not different. HBsAg and anti-HBs were determined by the hemagglutination method (Vyas and Shulman 1970). Fifty-six HBsAg-negative healthy persons with normal liver function tests and without a history of liver disease were served as control. None had received corticosteroid or other immunosuppressive drugs.

\section{Lymphocyte preparation}

Whole lymphocyte fraction (WLF) was obtained from $30 \mathrm{ml}$ of heparinized venous blood by Ficoll-Hypaque (F-H) gradient centrifugation (Böyum 1968), washed twice with phosphate buffered physiological saline (PBS, pH 7.4) and resuspended in RPMI 1640 medium (Nissui Seiyaku Co., Ltd., Tokyo) enriched with 10\% inactivated fetal calf serum (Microbiological Associates, Bethesda, USA), $100 \mathrm{U} / \mathrm{ml}$ penicillin and $100 \mu \mathrm{g} / \mathrm{ml}$ streptomycin (RPMI 1640-FCS). For AMLR macrophage-monocyte-depleted WLF (less than $3 \%$ ) was obtained by $\mathrm{F}-\mathrm{H}$ gradient centrifugation after incubation of venous blood with silica $\left(1 \mathrm{hr}\right.$ at $37^{\circ} \mathrm{C}, 10 \% \mathrm{KAC}-\mathrm{II}$ suspension, Japan Immunoresearch Laboratories Co., Ltd.). From WLF lymphocytes forming rosettes with sheep erythrocytes (E) previously treated with 2-S-aminoethylisothiouronium bromide (AET) as described by Kaplan et al. (1976) were separated by F-H gradient centrifugation as described previously (Nonomura et al. 1978). Lymphocytes lying at the bottom of the tubes were referred to as T-enriched fraction ( $\mathrm{T}$ ) and were recovered by lysis of the $\mathrm{E}$ with a $0.83 \% \mathrm{NH}_{4} \mathrm{Cl}$ in $20 \mathrm{mM}$ Tris buffer (pH 7.4) for 5 min, washed twice with PBS and resuspended in RPMI 1640-FCS. Lymphocytes remaining at the top of F-H were referred to as B-enriched fraction (B). They were collected, washed and resuspended in RPMI 1640-FCS.

\section{Testing for helper function of peripheral blood lymphocytes}

Methods described by Yata (1977) was used. T obtained from patients (Tp) and healthy persons (Tn) were suspended in RPMI 1640-FCS $\left(1 \times 10^{6}\right.$ cells $\left./ \mathrm{ml}\right)$. Responder B was prepared from a normal donor and suspended in RPMI 1640-FCS $\left(1 \times 10^{6}\right.$ cells $\left./ \mathrm{ml}\right)$. One donor served as the same source of responder $\mathrm{B}$ in all experiments. $0.2 \mathrm{ml}\left(2 \times 10^{5}\right.$ cells $)$ of $\mathrm{B}$ was mixed with $0.8 \mathrm{ml}\left(8 \times 10^{5}\right.$ cells $)$ of $\mathrm{Tp}(\mathrm{B}+\mathrm{Tp})$ or $0.8 \mathrm{ml}\left(8 \times 10^{5}\right.$ cells $)$ of $\mathrm{Tn}(\mathrm{B}+$ Tn) to yield a ratio of B to T of $1: 4$, together with $10 \mu \mathrm{g} / \mathrm{ml}$ of PWM, and incubated for 7 days in a humidified atmosphere of $95 \%$ air and $5 \% \mathrm{CO}_{2}$. One $\mathrm{ml}$ of responder $\mathrm{B}\left(2 \times 10^{5}\right.$ cells) only with PWM was also set up. In some experiments, the test was performed simultaneously at $\mathrm{B}$ to $\mathrm{T}$ ratios of 1 to 1,4 and 8 . After incubation, aliquots were cytocentrifuged onto glass slides, fixed in a solution of $95 \%$ ethanol and $5 \%$ acetic acid, and stained with fluorescent polyvalent anti-human immunoglobulin (Behring Institute, W. Germany). Cells with brightly stained cytoplasmic immunoglobulins were regarded as immunoglobulin producing cells (Ig-PC) (Siegal et al. 1976). The number of Ig-PC was counted and helper activity was determined by the number of $\mathrm{Ig}-\mathrm{PC}$ obtained at $\mathrm{T} / \mathrm{B}$ ratio of 4:1 as follows:

$$
\text { Helper activity }=\frac{\text { Number of } \operatorname{Ig}-\mathrm{PC} \text { in }(\mathrm{B}+\mathrm{Tp})-\text { Number of } \mathrm{Ig}-\mathrm{PC} \text { in } \mathrm{B}}{\text { Number of } \mathrm{Ig}-\mathrm{PC} \text { in }(\mathrm{B}+\mathrm{Tn})-\text { Number of } \mathrm{Ig}-\mathrm{PC} \text { in } \mathrm{B}} \times 100
$$

When Tn was used as Tp, helper activity was $100.8 \pm 22.1$ (mean \pm s.D., $n=21$ ).

\section{Testing for genuine helper function}

In certain experiments directed to test the genuine helper function of $\mathrm{T}, \mathrm{T}$ was previously $x$-irradiated with 2,000 rads to eliminate suppressor cell influences (Broder et al. 1978), since there were extensive data that suppressor $\mathrm{T}$ cells were relatively radiosensitive, whereas helper T cells were relative radioresistant (Rich and Pierce 1973; Dutton 1975; Keightley 
et al. 1976; Siegal and Siegal 1977). It has been reported that suppressor $\mathrm{T}$ cells are sensitive to this dose of $\mathrm{x}$-ray and their activities are nullified, whereas helper $\mathbf{T}$ cells are resistant (Broder et al. 1978). After irradiation, helper activity was tested as described above.

\section{Generation of suppressor cells by Con A}

Lymphocytes of WLF and T were divided respectively into two groups each containing $2 \times 10^{6}$ cells $/ \mathrm{ml}$ in RPMI 1640-FCS, which were incubated with or without (WLFCon A, T-Con A, WLF-C, and T-C, respectively) $10 \mu \mathrm{g} / \mathrm{ml}$ of Con A (Sigma Chemical Company, Saint Louis, USA) for $48 \mathrm{hr}$ at $37^{\circ} \mathrm{C}$ in a humidified incubator. Lymphocytes incubated without Con A (WLF-C, T-C) were used as control cells.

\section{Testing for Con A-induced suppressor function}

Suppression on differentiation of $B$ cells into Ig-PC. After incubation for $48 \mathrm{hr}$, both TCon A and T-C were washed once, suspended in fresh Eagle's minimum essential medium (MEM) (GIBCO, New York, USA) containing 0.1 M $a$-methyl-D-mannoside (P-L Biochemicals Inc., Milwaukee, USA) and incubated for $30 \mathrm{~min}$ at $37^{\circ} \mathrm{C}$ to remove Con A from lymphocytes. After incubation, cells were washed three times with MEM containing $5 \%$ FCS, tested for viability by trypan blue exclusion and finally resuspended in RPMI 1640-FCS at a concentration of $2 \times 10^{6} \mathrm{cells} / \mathrm{ml}$. Fresh responder B was prepared from a normal donor as described above and adjusted to a concentration of $2 \times 10^{6}$ cells $/ \mathrm{ml}$ in RPMI 1640-FCS. One donor served as the source of responder $\mathrm{B}$ in all experiments. $0.2 \mathrm{ml}$ of responder $\mathrm{B}$ and $0.2 \mathrm{ml}$ of T-Con A or T-C were mixed, together with $10 \mu \mathrm{g} / \mathrm{ml}$ of PWM (GIBCO, New York, USA) and incubated for 7 days at $37^{\circ} \mathrm{C}$ in a humidified atmosphere of $95 \%$ air and $5 \% \mathrm{CO}_{2}$. Cells were harvested, and counted. Ig-PC were counted as described above. The suppressor activity was determined as follows:

$$
\% \text { suppression }=100 \times\left(1-\frac{\text { Number of Ig-PC in the presence of T-Con A }}{\text { Number of Ig-PC in the presence of T-C }}\right)
$$

Suppression on the transformation responses of fresh allogeneic lymphocytes. After incubation for $48 \mathrm{hr}$, both WLF-Con A and WLF-C were treated with $50 \mu \mathrm{g} / \mathrm{ml}$ of mitomycin C (Sigma Chemical Company, Saint Louis, USA) for $30 \mathrm{~min}$ at $37^{\circ} \mathrm{C}$ to block DNA synthesis, and then washed three times with $30 \mathrm{mM}$ a-methyl-D-mannoside in RPMI-1640 medium. Cells were suspended in RPMI 1640-FCS, tested for viability by trypan blue exclusion and finally resuspended in RPMI 1640 -FCS $\left(1 \times 10^{6}\right.$ cells $\left./ \mathrm{ml}\right)$.

Fresh responder WLF were prepared from a normal donor as described above and adjusted to a concentration of $1 \times 10^{6} \mathrm{cells} / \mathrm{ml}$. One donor served as the source of responder cells in all experiments. One $\mathrm{ml}$ of responder WLF and one $\mathrm{ml}$ of WLF-Con A or WLF-C were mixed, together with $10 \mu \mathrm{g} / \mathrm{ml}$ of Con $\mathrm{A}$, and incubated for $72 \mathrm{hr}$ at $37^{\circ} \mathrm{C}$ in a humidified incubator. $24 \mathrm{hr}$ before harvesting, $2 \mu \mathrm{Ci}$ of $\left[{ }^{3} \mathrm{H}\right]$ thymidine (sp. act. $20 \mathrm{Ci} / \mathrm{mmole}$, the Radio Chemical Centre, Amersham, England) were added to each culture tube. After incubation cells were harvested and their radioactivities were measured for 2 min in a Beckman liquid scintillation counter. Tests were performed in quadruplicate. The suppressor activity was expressed in the following manner:

$$
\% \text { suppression }=100 \times\left(1-\frac{\left[{ }^{3} \mathrm{H}\right] \text { thymidine incorporation in the presence of WLF-Con A }}{\left[{ }^{3} \mathrm{H}\right] \text { thymidine incorporation in the presence of WLF-C }}\right)
$$

\section{Effect of CAH sera on Con A-induced suppressor function of healthy lymphocytes}

WLF from healthy subjects was preincubated with heat-inactivated test serum $\left(56^{\circ} \mathrm{C}\right.$ for $\left.30 \mathrm{~min}\right)$ for $12 \mathrm{hr}$ at $37^{\circ} \mathrm{C}$ in a humidified atmosphere of $95 \%$ air and $5 \% \mathrm{CO}_{2}$ $\left(2 \times 10^{6} \mathrm{cells} / \mathrm{ml}\right.$ serum $)$, then washed and resuspended in RPMI 1640 -FCS $\left(2 \times 10^{6} \mathrm{cells} / \mathrm{ml}\right)$. The suspension was divided into two groups and incubated for $48 \mathrm{hr}$ with or without Con A to generate suppressor cells, and then Con A-induced suppressor function on blast transformation responses of allogeneic lymphocytes was studied as described above. 


\section{Autologous $M L R$}

$\mathrm{T}$ and $\mathrm{B}$ were obtained from macrophage-monocyte-depleted WLF as described above. B was treated with mitomycin C $(50 \mu \mathrm{g} / \mathrm{ml})$ (Sigma Chemicals Co.) for $30 \mathrm{~min}$ at $37^{\circ} \mathrm{C}$, then washed and resuspended in RPMI 1640 -FCS. $0.5 \mathrm{ml}$ of responding $\mathrm{T}\left(1 \times 10^{5}\right.$ cells) and $0.5 \mathrm{ml}$ of stimulating $\mathrm{B}\left(1 \times 10^{5}\right.$ cells $)$ were mixed and incubated for $168 \mathrm{hr}$ at $37^{\circ} \mathrm{C}$ in a $5 \% \mathrm{CO}_{2} / 95 \%$ air humidified atmosphere. At $24 \mathrm{hr}$ before the termination of the incubation period, $1 \mu \mathrm{Ci}$ of $\left[{ }^{3} \mathrm{H}\right]$ thymidine (sp. act. $20 \mathrm{Ci} / \mathrm{mmole}$, the Radio Chemical Centre, Amersham, England) was added to each culture tube. After incubation cells were harvested and their radioactivities were measured for $2 \mathrm{~min}$ in a Beckman liquid scintillation counter. Tests were performed in triplicate. Results were recorded as the difference in cpm in stimulated and unstimulated culture (responding $\mathrm{T}$ cell alone).

\section{Results}

\section{Spontaneous helper function}

Helper activity. The number of $\mathrm{Ig}-\mathrm{PC}$ after 7 day-incubation of $\mathrm{B}$ with $\mathrm{T}$ at various $\mathrm{T} / \mathrm{B}$ ratios, together with $\mathrm{PWM}$, is shown in Fig. 1 (open column). The number of $\mathrm{Ig}-\mathrm{PC}$ at all respective $\mathrm{T} / \mathrm{B}$ ratios tested in patients with $\mathrm{CAH}$ was significantly increased in comparison with corresponding results of healthy subjects $(p<0.01)$, whereas those of $\mathrm{CPH}$ were not significant. The spontaneous helper activity was calculated from the data tested at $\mathrm{T} / \mathrm{B}$ ratio of $4 / 1$ (a physiological $\mathrm{T} / \mathrm{B}$ ratio in peripheral blood lymphocytes in healthy subjects). As

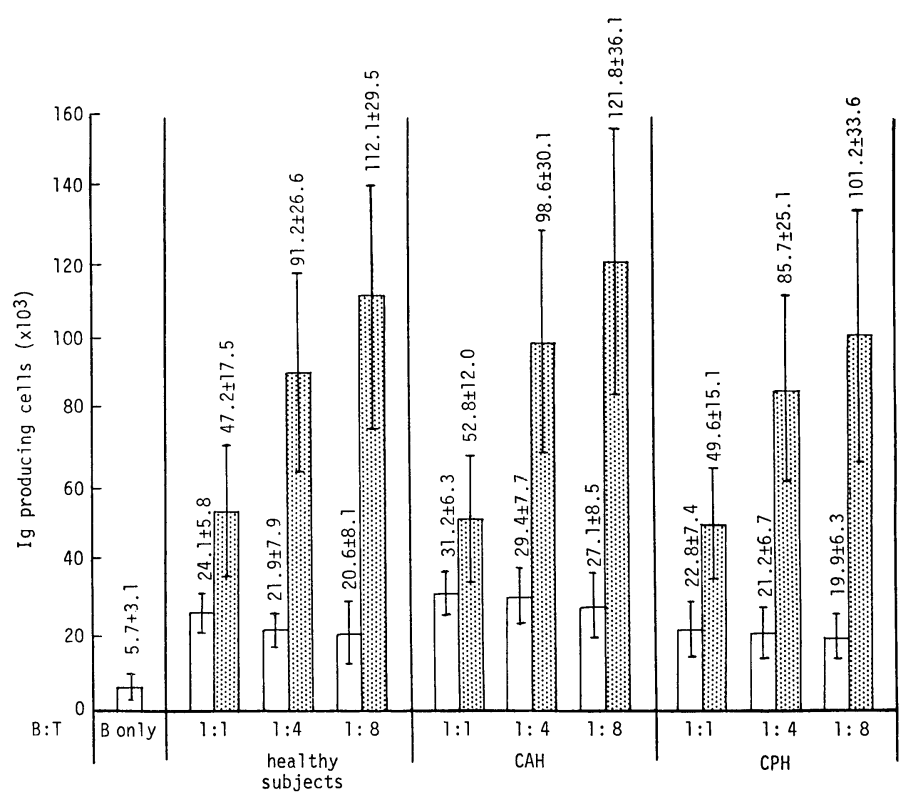

Fig. 1. Numbers of Ig-producing cells after 7 day-incubation of B cells from a nomral subject with $\mathrm{T}$ cells (open columns) or irradiated $\mathrm{T}$ cells (2,000 rads, shaded columns) from healthy subjects $(n=11)$, patients with chronic active hepatitis (CAH, $n=11)$ and patients with chronic persistent hepatitis $(\mathrm{CPH}, n=11)$ at various $\mathrm{T}$ or irradiated $\mathrm{T}$ to B ratios, together with $10 \mu \mathrm{g} / \mathrm{ml}$ of PWM. Results and bars shown represent means \pm s.D. 


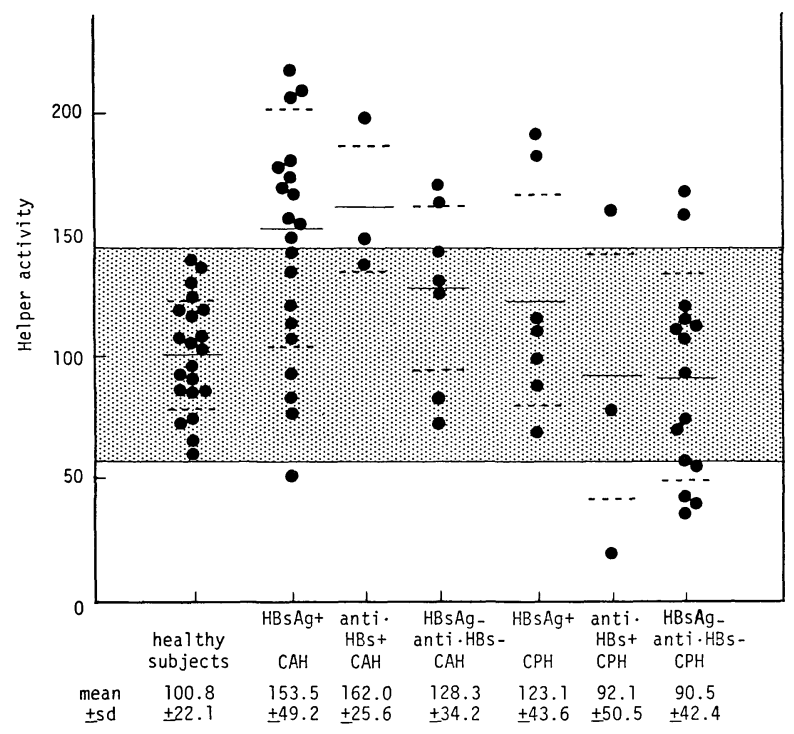

Fig. 2. The results of spontaneous helper activity on B cell differentiation into Igproducing cells in patients with chronic hepatitis and healthy subjects. Results are given as the mean \pm s.D. Shaded area indicates the range of mean \pm 2 s.D. of healthy subjects $(n=21)$. Abbreviations: CAH, chronic active hepatitis; CPH, chronic persistent hepatitis; $\mathrm{HBsAg}+, \mathrm{HBsAg}$ positive; $\mathrm{HBsAg}-$, HBsAg negative; anti-HBs + , anti-HBs positive; anti-HBs-, anti-HBs negative.

(\%)

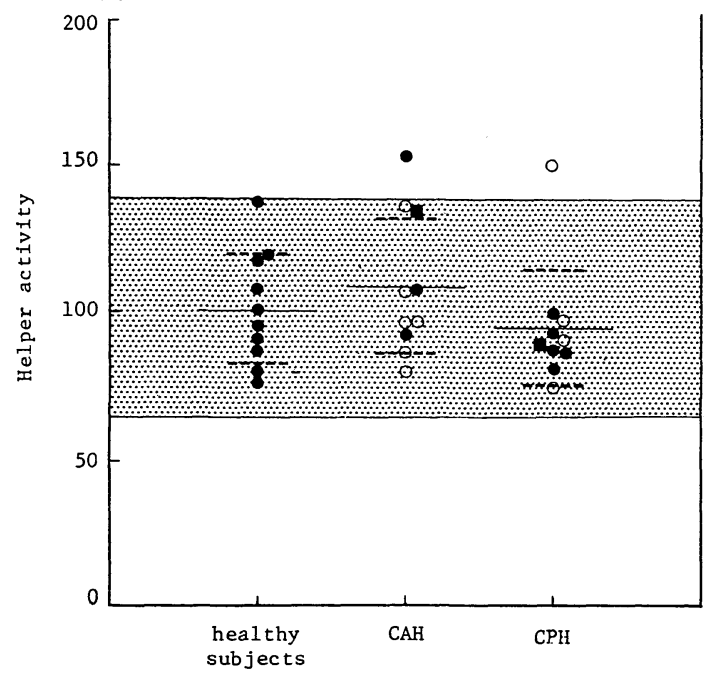

Fig. 3. The results of genuine spontaneous helper activity in patients with chronic hepatitis and healthy subjects. Bars represent mean \pm s.D. Shaded area indicates the mean \pm 2 s.D. of the healthy subjects. •, both HBsAg- and anti-HBs-negative case, $\mathrm{O}$, HBsAg-positive case; anti-HBs-positive case. Abbreviations are the same as in Fig. 2. 
shown in Fig. 2, mean spontaneous helper activity of HBsAg-positive CAH, antiHBs-positive $\mathrm{CAH}$ or both $\mathrm{HBsAg-}$ and anti-HBs-negative $\mathrm{CAH}$ was significantly higher than that of healthy subjects $(p<0.01, p<0.001$ and $p<0.05$, respectively), whereas those of $\mathrm{CPH}$ were not significant. Mean helper activity was not different in the subgroups of $\mathrm{CAH}$. When normal range was taken as mean \pm 2 s.D. in healthy subjects and each patient who showed a helper activity higher or lower than this value was considered respectively to be positive helper or suppressor activity, 15 (11 HBsAg-positive, 2 anti-HBs-positive, 2 both $\mathrm{HBsAg}$ - and antiHBs-negative) of 30 patients with $\mathrm{CAH}$ and 5 (2 HBsAg-positive, 1 anti-HBs-positive, 2 both HBsAg- and anti-HBs-negative) of 25 with $\mathrm{CPH}$ showed positive helper activity, and one (HBsAg-positive) of 30 patients with $\mathrm{CAH}$ and 5 (1 anti-HBsAgpositive, 4 both $\mathrm{HBsAg}$ - and anti-HBs-negative) of 25 with $\mathrm{CPH}$ showed positive suppressor activity (Fig. 2).

Genuine helper activity. The number of Ig-PC on 7 day-incubation of B with increasing numbers of $\mathrm{X}$-ray irradiated $\mathrm{T}$ cells is shown in Fig. 1 (shaded column). A sharp increase in number of Ig-PC was observed with increasing numbers of $\mathrm{X}$-ray irradiated $\mathrm{T}$ cells in all groups tested and the mean number of Ig-PC at the same T/B ratio was significantly increased when compared to that obtained from the test using non-irradiated T cells $(p<0.001)$, but the mean number of Ig-PC at the same irradiated $\mathrm{T} / \mathrm{B}$ ratio was not significantly different between groups tested. Healthy subjects and $\mathrm{CAH}$ or $\mathrm{CPH}$ were not different in genuine helper activity (Fig. 3).

\section{Con A-induced suppressor function}

Suppressor activity on lymphocyte blast transformation. The results are shown in Fig. 4. Mean Con A-induced suppressor activity of each subgroup of CAH was significantly decreased when compared to healthy subjects $(p<0.001, p<0.01$ and $p<0.001$, respectively). Mean suppressor activities of anti-HBs-positive CPH and both HBsAg- and anti-HBs-negative $\mathrm{CPH}$ were also significantly decreased in lesser degrees $(p<0.05$ and $p<0.05$, respectively). However, no difference in mean Con A-induced suppressor activity was noted between any two subgroups of CAH or CPH. Significantly decreased suppressor activity, judged by a value less than mean-2s.D. of the healthy subjects, was demonstrated in 4 of 10 patients with $\mathrm{HBsAg}$-positive $\mathrm{CAH}, 1$ of 2 with anti-HBs-positive CAH, 4 of 6 with both HBsAgand anti-HBs-negative $\mathrm{CAH}$ and 2 of 9 with both HBsAg- and anti-HBs-negative $\mathrm{CPH}$.

Suppressor activity on differentiation of $B$ cells into Ig-PC. The results are shown in Fig. 5. Mean suppressor activity of HBsAg-positive $\mathrm{CAH}$ and both $\mathrm{HBsAg}$ - and anti-HBs-negative $\mathrm{CAH}$ was significantly decreased as compared with that of healthy subjects $(p<0.001$ and $p<0.001$, respectively). The mean value of both HBsAg-and anti-HBs-negative CPH was also significantly decreased $(p<$ 0.05). Significantly decreased suppressor activity, judged by a value less than 


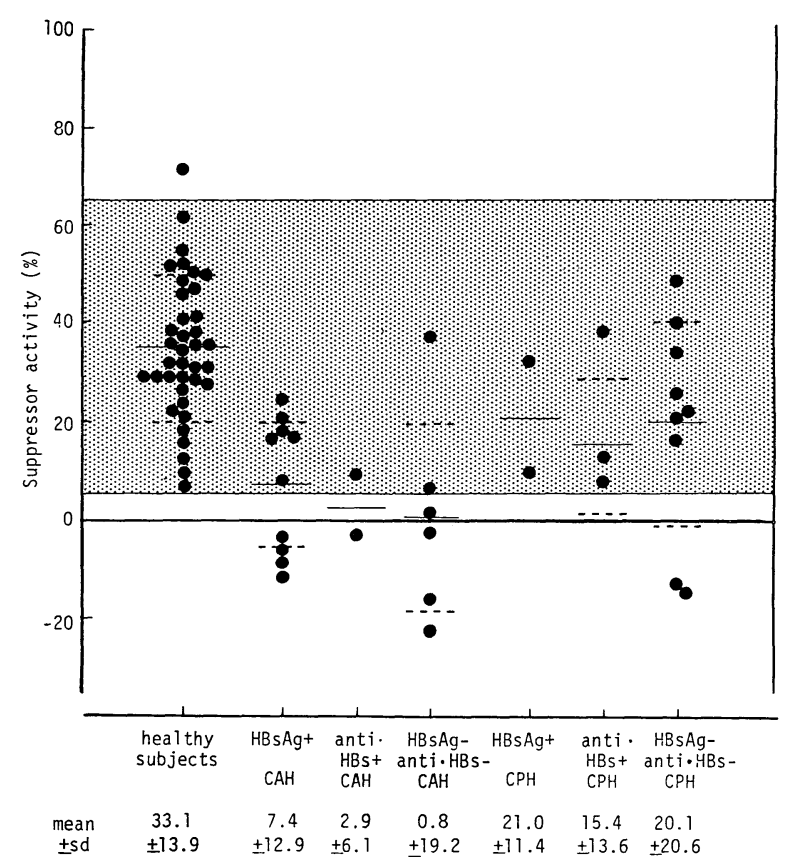

Fig. 4. The results of Con-A induced suppressor cell function on lymphocyte blast transformation responses. Results and bars shown represent mean \pm s.D. Shaded area indicates the range of mean \pm 2 s.D. of healthy subjects $(n=38)$. Abbreviations are the same as in Fig. 2.

mean-2s.D. of the healthy subjects, was found in 7 of 10 patients with $\mathrm{CAH}$ and 1 of 10 with $\mathrm{CPH}$.

Effects of CAH sera on Con A-induced suppressor activity of healthy subjects

The results are shown in Fig. 6. Con A-induced suppressor activity of healthy subjects was significantly decreased after preincubation of lymphocytes with HBsAg-positive $\mathrm{CAH}$ sera or both $\mathrm{HBsAg}$ - and anti-HBs-negative $\mathrm{CAH}$ sera $(p<$ 0.01 and $p<0.005$, respectively). Sera from patients with both HBsAg- and anti-HBs-negative $\mathrm{CPH}$ also inhibited suppressor cell function of healthy subjects $(p<0.005)$. Significantly inhibitory sera, judged by a value less than mean-2s.D. of the healthy subjects, was found in 5 of 13 patients with $\mathrm{HBsAg}$-positive $\mathrm{CAH}$, 2 of 8 both HBsAg- and anti-HBs-negative CAH, 1 of $7 \mathrm{HBsAg-positive} \mathrm{CPH}$ and 1 of 7 both HBsAg- and anti-HBs-negative CPH.

Autologous mixed lymphocyte reaction (AMLR)

The results are shown in Fig. 7. The test was performed in 22 patients with CAH (14 HBsAg-positive, 8 both HBsAg- and anti-HBs-negative) and 13 with CPH (2 HBsAg-positive, 2 anti-HBs-positive and 9 both HBsAg- and anti-HBsnegative). Mean AMLR of patients with $\mathrm{CAH}$ was significantly decreased as 


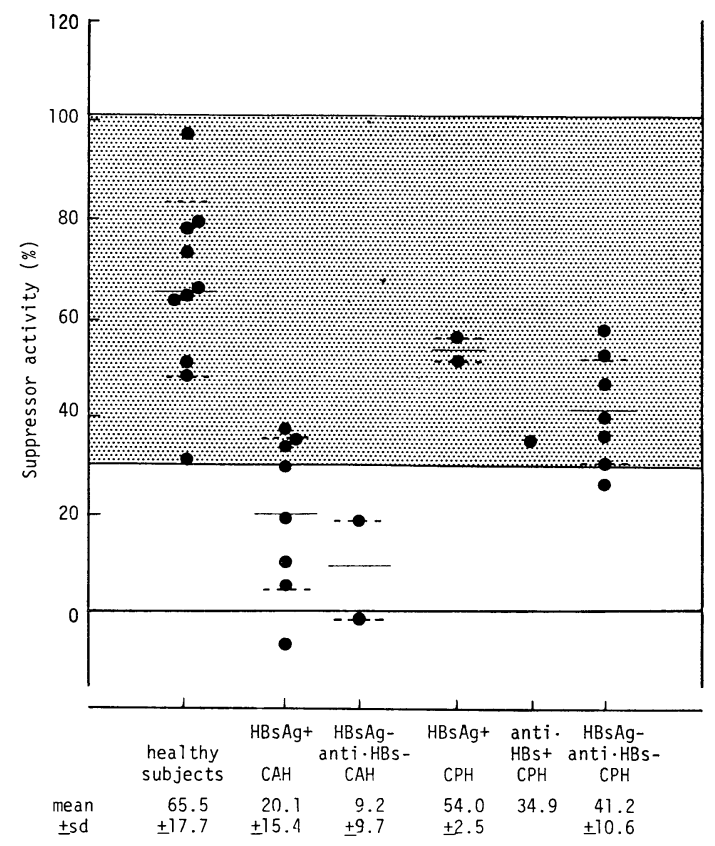

Fig. 5. The results of Con A-induced suppressor cell function on B cell differentiation into Ig-producing cells in patients with chronic hepatitis and healthy subjects. Results and bars shown represent mean \pm s.D. Shaded area indicates the range of mean \pm 2 s.D. of healthy subjects $(n=10)$. Abbreviations are the same as in Fig. 2.

compared with that of healthy subjects $(p<0.005)$, whereas that of $\mathrm{CPH}$ was not significant. Mean AMLR was not different in patients with HBsAg-positive CAH and those with both HBsAg- and anti-HBs-negative CAH $(2,610.3 \pm 1,352.2$ vs. $4,297.9 \pm 2,647.8)$. Mean AMLR of patients with both HBsAg- and anti-HBsnegative $\mathrm{CPH}(n=9,4,319.2 \pm 1,522.2)$ was also significantly decreased as compared with that of healthy subjects $(p<0.05)$.

\section{Discussion}

Evidence has been accumulated that development of autoimmune diseases in animal model systems (Gerber et al. 1974; Krakauer et al. 1976; Eardley et al. 1978; Cantor et al. 1978) and in human beings (Abdou et al. 1976; Bresnihan and Jasin 1977; Horowitz et al. 1977; Sakane et al. 1978; Strelkauskas et al. 1978; Sagawa and Abdou 1979) may result from defective immunoregulatory suppressor $\mathrm{T}$ cell functions. The similar abnormality of suppressor $\mathrm{T}$ cell function was postulated to be one of the causes of CAH (Eddleston and Williams 1974). The present study demonstrated that peripheral blood lymphocytes from patients with CAH have defective suppressor cell activity and decreased AMLR. The similar suppressor cell alteration in a lesser degree was also demonstrated in patients with HBsAgnegative CPH when tested by Con A-induced suppressor systems. Although patients 


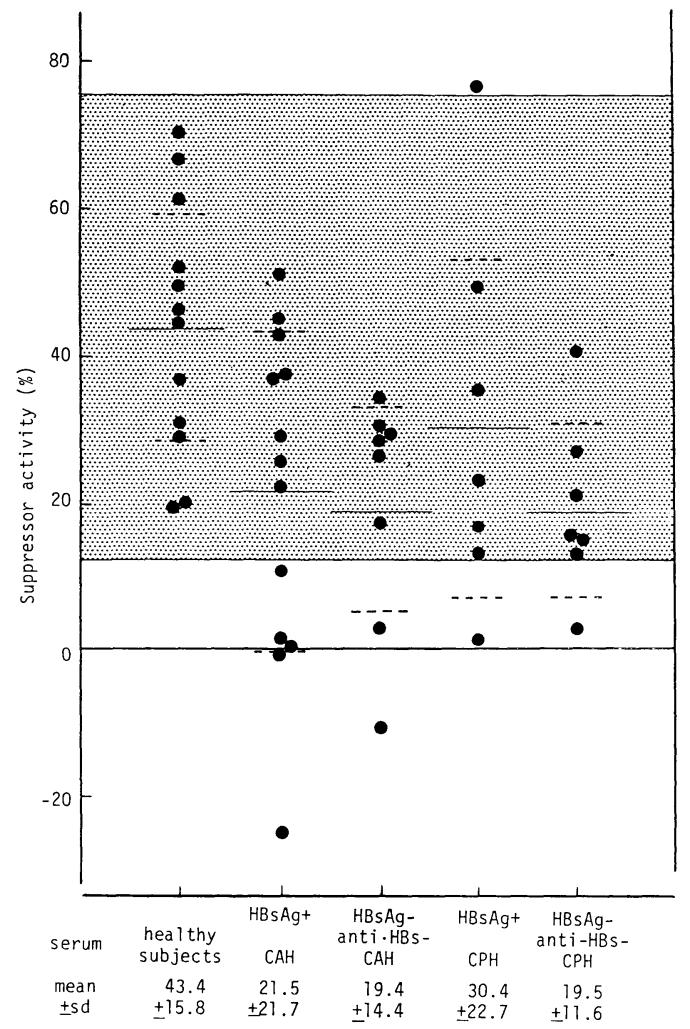

Fig. 6. Effects of preincubation of healthy lymphocytes with sera of patients with chronic hepatitis on Con A-induced suppressor cell function. Results and bars shown represent mean \pm s.D. Shaded area indicates the range of mean $\pm 2 \mathrm{~s} . \mathrm{D}$. of healthy subjects $(n=12)$. Abbreviations are the same as in Fig. 2.

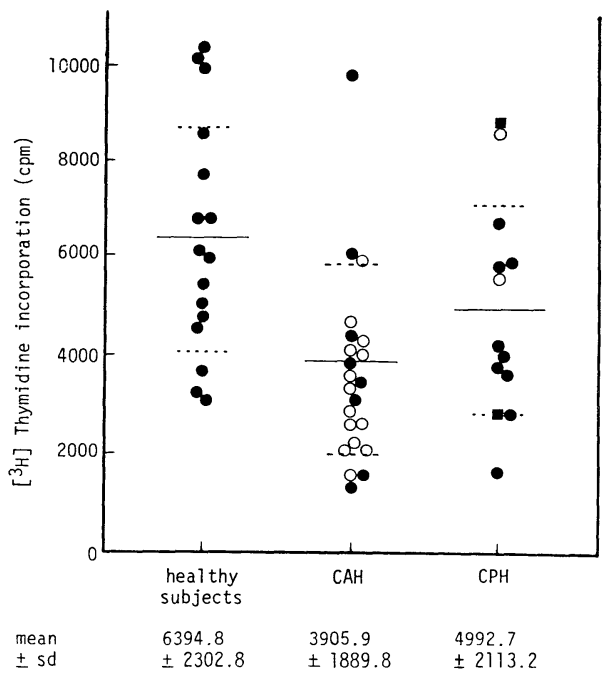

Fig. 7. Autologous MLR between $\mathrm{T}$ and non-T cells in patients with chronic hepatitis and healthy subjects. Results and bars shown represent mean \pm s.D. •, both

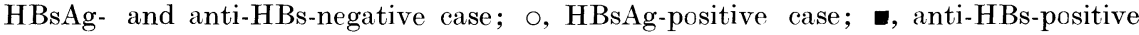
case. Abbreviations are the same as in Fig. 2. 
who had poor Con A-induced suppressor activity tended to be found in HBsAgnegative cases, no statistically significant difference in mean suppressor activity was found between HsBAg-positive and HBsAg-negative cases with $\mathrm{CAH}$ or $\mathrm{CPH}$ (Fig. 4). Nor difference in spontaneous suppressor cell activity was found between HBsAg-positive and HBsAg-negative cases, either. The results are considered to be consistent with previous reports that humoral antibody and cell-mediated immunity to liver-specific membrane lipoprotein (LSP) were found with an equal frequency in HBsAg-positive and HBsAg-negative CAH (Chisari et al. 1978; Meyer zum Büschenfelde et al. 1979; Kakumu et al. 1979).

There are a number of possible explanations for the altered suppressor cell activity in chronic hepatitis. A generalized $\mathrm{T}$ lymphocyte hyporesponsiveness (Rössler et al. 1969; Martini et al. 1970; Giustino et al. 1972; Dudley et al. 1972; Toh et al. 1973) and a decrease in number and percentage of peripheral blood $\mathrm{T}$ lymphocytes (DeHoratius et al. 1974; Thomas et al. 1976; Colombo et al. 1977; Williams et al. 1980) heve been reported by several investigators in patients with chronic hepatitis, particularly in CAH. Our present data suggested that a serum factor(s) present in $\mathrm{CAH}$ patients may alter suppressor lymphocyte function of healthy subjects. Natures of the serum factor(s) were not characterized in our experiments. However, several investigators reported the presence of serum factor which may derange the functions of $\mathrm{T}$ lymphocytes in patients with chronic hepatitis (Wands et al. 1975; Dehoratius et al. 1976; Chisari et al. 1977, 1978; Kakumu et al. 1978). Dehoratius et al. (1976) emphasized a presence of lymphocytotoxins in sera of chronic hepatitis in relation to decreased peripheral $\mathrm{T}$ lymphocytes. Chisari et al. (1977) demonstrated the presence of serum factor that inhibits the function of $\mathrm{T}$ lymphocytes forming rosettes with sheep erythrocytes in $\mathrm{CAH}$ and acute hepatitis. They termed it rosette inhibitory factor (RIF). Furthermore, Chisari et al. (1978) reported that the presence of RIF is concordant with the frequent presence of decreased suppressor activity and this association of RIF with decreased suppressor cell activity is also concordant with evidence of sensitization and cytotoxicity towards a hepatocellular autoantigen (LSP). Finally the presense of autoantibody that would appear to have a specificity against suppressor $\mathrm{T}$ cells has been reported in juvenile rheumatoid arthritis (Strelkauskas et al. 1978) and SLE (Sagawa and Abdou 1979). An analogous antibody has been reported in NZB and NZB/W mice (Shirai and Mellors 1971; Klassen et al. 1977) which have been well known to develop autoimmunity mimicking human SLE. Additional serum factors such as lipoproteins, alpha fetoprotein and bile acid have been reported to suppress the lymphocyte functions (Chisari et al. 1978; Gianni et al. 1980). The precise nature of serum inhibitory factor(s) related to liver diseases or its relationship to suppressor $\mathrm{T}$ cell function has not yet been defined and remains to be clarified.

In the present study, AMLR was significantly decreased in patients with CAH. Analogous results have been reported in patients with SLE (Sakane et al. 1978) and Sjögren's syndrome (Miyasaka et al. 1980) and in the SLE model in NZB mice 
(Smith and Pasternak 1978). Although the exact biologic role of the AMLR has not been fully established, it is assumed to reflect an important immunoregulatory function (Opelz et al. 1975; Kuntz et al. 1976; Sakane et al. 1978). Recently, evidence is accumulating that AMLR and Con A-induced suppressor cell activity are closely related to each other. Sakane and Green (1979) reported that autoreactive $\mathrm{T}$ cells capable of responding to autologous non-T cells are particularly enriched in cells capable of becoming Con A-induced suppressor cells. Innes et al. (1979) reported that AMLR may play an important role in generation of suppressor cells by Con A. So it seems to be understandable that both Con A-induced suppressor cell activity and AMLR were decreased in patients with CAH.

Although our investigation was directed to non-specific suppressor functions, the data presented herein suggest that decreased suppressor cell activity reflects altered immune responses of chronic hepatitis and may be related to the pathogenesis of some CAH. To clarify the precise immunopathological mechanisms involved in $\mathrm{CAH}$, specific helper or suppressor cell function induced by, for example, liver specific antigen and hepatitis-related viral-associated antigens are required to be evaluated.

\section{References}

1) Abdou, N.I., Sagawa, A., Pascual, E., Hebert, J. \& Sadeghee, S. (1976) Suppressor T-cell abnormality in idiopathic systemic lupus erythematosus. Clin. Immunol. Immunopath., 6, 192-199.

2) Alberti, A., Realdi, G., Tremolada, F. \& Spina, G.P. (1976) Liver cell surface localization of hepatitis B antigen and of immunoglobulins in acute and chronic hepatitis and in liver cirrhosis. Clin. exp. Immunol., 25, 396-402.

3) Bacon, P.A., Berry, H. \& Bown, R. (1972) Cell-mediated immune reactivity in liver disease. Gut, 13, 427-429.

4) Böyum, A. (1968) Separation of leucocytes from blood and bone marrow. Scand. J.clin. Lab. Invest., 21, Suppl. 97, 1-109.

5) Bresnihan, B. \& Jasin, H.E. (1977) Suppressor function of peripheral blood mononuclear cells in normal individuals and in patients with systemic lupus erythematosus. J. clin. Invest., 59, 106-116.

6) Broder, S., Poplack, D., Whang-Peng, J., Durm, M., Goldman, C., Muul, L. \& Waldmann, T.A. (1978) Characterization of a suppressor-cell leukemia. Evidence for the requirement of an interaction of two $\mathbf{T}$ cells in the development of human suppressor effector cells. New Engl. J. Med., 298, 66-72.

7) Cantor, H., McVay-Boudreau, L., Hugenberger, J., Naidorf, K., Shen, F.W. \& Gershon, R.K. (1978) Immunoregulatory circuits among $\mathrm{T}$ cells sets. II. Physiologic role of feedback inhibition in vivo; absence in NZB mice. J. exp. Med., 147, 1116-1125.

8) Chalmers, T.C., Zimmerman, H., Summerskill, W.H.J. \& Mosley, J.W. (1974) Nomenclature, diagnostic criteria and diagnostic methodology for diseases of the liver and biliary tract. In: Fogarty International Center Proceedings. No. 22, edited by H. Popper, S. Sherlock, C.M. Leevy \& M.I. Haris, Plenum Press, New York, pp. 21-24.

9) Chisari, F.V., Routenberg, J.A., Fiala, M. \& Edgington, T.S. (1977) Extrinsic modulation of human T-lymphocyte $\mathrm{E}$ rosette function associated with prolonged hepatocellular injury after viral hepatitis. J. clin. Invest., 59, 134-142.

10) Chisari, F.V., Routenberg, J.A., Anderson, D.A. \& Edgington, T.S. (1978) Cellular immune reactivity in $\mathrm{HBV}$-induced liver disease. In: Viral Hepatitis, Edited by G.N. Vyas, S.N. Cohen \& R. Schmid. The Franklin Institute Press, Philadelphia, pp. 245266. 
11) Colombo, M., Vernace, S.J. \& Paronetto, F. (1977) T and B lymphocytes in patients with chronic active hepatitis (CAH). Clin. exp. Immunol., 30, 4-9.

12) DeHoratius, R.J., Strickland, R.G. \& Williams, R.C., Jr. (1974) T and B lymphocytes in acute and chronic hepatitis. Clin. Immunol. Immunopath., 2, 353-360.

13) Dehoratius, R.J., Henderson, C. \& Strickland, R.G. (1976) Lymphocytotoxins in acute and chronic hepatitis. Characterization and relationship to changes in circulating T lymphocytes. Clin. exp. Immunol., 26, 21-27.

14) Doniach, D. \& Walker, J.G. (1969) A unified concept of autoimmune hepatitis. Lancet, 1, 813-815.

15) Dudley, F.J., Fox, R.A. \& Sherlock, S. (1972) Cellular immunity and hepatitisassociated, Australia antigen liver disease. Lancet, 1, 723-726.

16) Dutton, R.W. (1975) Suppressor T cells. Transplant. Rev., 26, 39-55.

17) Eardley, D.D., Hugenberger, J., McVay-Boudreau, L., Shen, F.W., Gershon, R.K. \& Cantor, H. (1978) Immunoregulatory circuits among T-cell sets. I. T-helper cells induce other T-cell sets to exert feedback inhibition. J. exp. Med., 147, 1106-1115.

18) Eddleston, A.L.W.F. \& Williams, R. (1974) Inadequate antibody response to HBAg or suppressor $\mathrm{T}$-cell defect in development of active chronic hepatitis. Lancet, $\mathbf{2}$, $1543-1545$.

19) Gerber, N.L., Hardin, J.A., Chused, T.M. \& Steinberg, A.D. (1974) Loss with age in NZB/W mice of thymic suppressor cells in the graft-vs-host reaction. J. Immunol., $113,1618-1625$.

20) Gershon, R.K. (1974) T cell control of antibody production. Contemp. Top. Immunobiol., 3, 1-40.

21) Geubel, A.P., Keller, R.H., Summerskill, W.H.J., Dickson, E.R., Tomasi, T.B. \& Shorter, R.G. (1976) Lymphocyte cytotoxcity and inhibition studied with autologous liver cells; observations in chronic active liver disease and the primary biliary cirrhosis syndrome. Gastroenterology, 71, 450-456.

22) Gianni, L., Dipadova, F., Zuin, M. \& Podda, M. (1980) Bile acid-induced inhibition of the lymphoproliferative response to phytohemagglutinin and pokeweed mitogen; an in vitro study. Gastroenterology, 78, 231-235.

23) Giustino, V., Dudley, F.J. \& Sherlock, S. (1972) Thymus-dependent lymphocyte function in patients with hepatitis-associated antigen. Lancet, 2, 850-853.

24) Hodgson, H.J.F., Wands, J.R. \& Isselbacher, K.J. (1978) Decreased suppressor cell activity in inflammatory bowel disease. Clin. exp. Immunol., 32, 451-458.

25) Hopf, U., Arnold, W., Meyer zum Büschenfelde, K.H., Forster, E. \& Bolte, J.P. (1975) Studies on the pathogenesis of chronic inflammatory liver disease. 1. Membrane-fixed IgG on isolated hepatocytes from patients. Clin. exp. Immunol., 22, $1-8$.

26) Hopf, U., Meyer zum Büschenfelde, K.H. \& Arnold, W. (1976) Detection of a liver membrane autoantibody in HBsAg-negative chronic active hepatitis. New Engl. J. Med., 294, 578-582.

27) Horowitz, S., Borcherding, W., Moorthy, A.V., Chesney, R., Schulte-Wisserman, H. \& Hong, R. (1977) Induction of suppressor T cells in systemic lupus erythematosus by thymosin and cultured thymic epithelium. Science, 197, 999-1001.

28) Innes, J.B., Kuntz, M.M., Kim, Y.T. \& Weksler, M.E. (1979) Induction of suppressor activity in the autologous mixed lymphocyte reaction and in cultures with Concanavalin A. J. clin. Invest., 64, 1608-1613.

29) Jensen, D.M., McFarlane, I.G., Protmann, B.S., Eddleston, A.L.W.F. \& Williams, R. (1978) Defection of antibodies directed against a liver specific membrane lipoprotein in patients with acute and chronic active hepatitis. New Engl. J. Med., 299, 1-7.

30) Kakumu, S., Hara, T., Gohji, H. \& Sakamoto, N. (1978) Inhibition of lymphocyte cytotoxicity in chronic active hepatitis. Clin. exp. Immunol., 33, 71-78.

31) Kakumu, S., Arakawa, Y., Goji, H., Kashio, T. \& Yata, K. (1979) Occurrence and significance of antibody to liver-specific membrane lipoprotein by double-antibody immunoprecipitation method in sera of patients with acute and chronic liver diseases. Gastroenterology, 76, 665-672. 
32) Kaplan, M.E., Woodson, M. \& Clark, C. (1976) Detection of human T lymphocytes by rosette formation with AET-treated sheep red cells. In: In Vitro Methods in Cell-Mediuted and Tumor Immunity, edited by B.R. Bloom \& J.R. David, Academic Press, New York, pp. 83-88.

33) Kawanishi, H. \& MacDermott, R.P. (1979) K-cell-mediated antibody-dependent cellular cytotoxicity in chronic active liver disease. Gastroenterology, 76, 151-158.

34) Keightley, R.G., Cooper, M.D. \& Lawton, A.R. (1976) The T cell dependence of B cell differentiation induced by pokeweed mitogen. J. Immunol., 117, 1538-1544.

35) Klassen, L.W., Krakauer, R.S. \& Steinberg, A.D. (1977) Selective loss of suppressor cell function in New Zealand mice induced by NTA. J. Immunol., 119, 830-837.

36) Krakauer, R.S., Waldmann, T.A. \& Strober, W. (1976) Loss of suppressor T-cells in adult NZB/NZW mice. J. exp. Med., 144, 662-673.

37) Kuntz, M.M., Innes, J.B. \& Weksler, M.E. (1976) Lymphocyte transformation by autologous cells. IV. Human T-lymphocyte proliferation induced by autologous or allogeneic non-T lymphocytes. J. exp. Med., 143, 1042-1054.

38) Lee, W.M., Reed, W.D., Mitchell, C.G., Galbraith, R.M., Eddleston, A.L.W.F., Zuckerman, A.J. \& Williams, R. (1975) Cellular and humoral immunity to hepatitisB surface antigen in active chronic hepatitis. Brit. med. J., 1, 705-708.

39) Martini, G.A., Roessler, R., Havemann, K. \& Doelle, W. (1970) Inhibited lymphocytic response to phytohemagglutinin (PHA) in acute infectious hepatitis and in chronic aggressive hepatitis; indirect evidence for virus persistence in chronic aggressive hepatitis? Scand. J. Gastroent., Suppl. 7, 39-42.

40) Meyer zum Büschenfelde, K.H., Knolle, J. \& Berger, J. (1974) Celluläre Immunreaktionen gegenüber homologen leberspezifischen Antigenen (HLP) bei chronischen Leberentzündungen. Klin. Wschr., 52, 246-248.

41) Meyer zum Büschenfelde, K.H., Hütteroth, T.H., Arnold, W. \& Hopf, U. (1979) Immunologic liver injury: The role of hepatitis $\mathrm{B}$ viral antigens and liver membrane antigens as targets. Prog. Liver Disease, 4, 407-424.

42) Miller, J., Smith, M.G.M., Mitchell, C.G., Reed, W.D., Eddleston, A.L.W.F. \& Williams, R. (1972) Cell-mediated immunity to a human liver-specific antigen in patients with active chronic hepatitis and primary biliary cirrhosis, Lancet, 2, 296-297.

43) Miyasaka, N., Sauvezie, B., Pierce, D.A., Daniels, T.E. \& Talal, N. (1980) Decreased autologous mixed lymphocyte reaction in Sjögren's syndrome. J. clin. Invest., 66, 928-933.

44) Nonomura, A., Shintani, T. \& Ohta, G. (1978) Lymphocyte cytotoxicity to cultured rat liver cells in patients with chronic liver disease. Tohoku J. exp. Med., 126, 159-171.

45) Opelz, G., Kiuchi, M., Takasugi, M. \& Terasaki, P.I. (1975) Autologous stimulation of human lymphocyte subpopulations. J. exp. Med., 142, 1327-1333.

46) Paronetto, F. \& Vernace, S. (1975) Immunological studies in patients with chronic active hepatitis. Cytotoxic activity of lymphocytes to autochthonous liver cells 'grown in tissue culture. Clin. exp. Immunol., 19, 99-104.

47) Rich, R.R. \& Pierce, C.W. (1973) Biological expressions of lymphocyte activation. II. Generation of a population of thymus-derived suppressor lymphocytes. $J$. exp. Med., 137, 649-659.

48) Rössler, R., Havemann, K. \& Döller, W. (1969) Unterschiedliche Reaktion von Lymphocyten und Phythämagglutinin (PHA) bei Leberenkrankungen. Klin. Wschr., 47, 803-806.

49) Rose, N.R. (1978) Autoimmunity revisited. Nature, 275, 88-90.

50) Sagawa, A. \& Abdou, N.I. (1979) Suppressor cell antibody in systemic lupus erythematosus; possible mechanism for suppressor cell dysfunction. J. clin. Invest., 63, 536-539.

51) Sakane, T. \& Green, I. (1979) Specificity and suppressor function of human T cells responsive to autologous non-T cells. J. Immunol., 123, 584-589.

52) Sakane, T., Steinberg, A.D. \& Green, I. (1978) Failure of autologous mixed lymphocyte reactions between $\mathrm{T}$ and non- $\mathrm{T}$ cells in patients with systemic lupus erythematosus. Proc. nat. Acad. Sci. USA, 75, 3464-3468. 
53) Shirai, T. \& Mellors, R.C. (1971) Natural thymocytotoxic autoantibody and reactive antigen in New Zealand Black and other mice. Proc. nat. Acad. Sci. USA, 68, 14121415 .

54) Siegal, E.P., Siegal, M. \& Good, R.A. (1976) Suppression of B-cell differentiation by leukocytes from hypogammaglobulinemic patients. J. clin. Invest., 58, 109-122.

55) Siegal, E.P. \& Siegal, M. (1977) Enhancement by irradiated T cells of human plasma cell production; dissection of helper and suppressor functions in vitro. J. Immunol., 118, 642-647.

56) Smith, J.B. \& Pasternak, R.D. (1978) Syngeneic mixed lymphocyte reaction in mice: Strain distribution, kinetics, participating cells and absence in NZB mice. $J$. Immunol., 121, 1889-1892.

57) Smith, M.G.M., Golding, P.L., Eddleston, A.L.W.F., Mitchell, C.G., Kemp. A. \& Williams, R. (1972) Cell-mediated immune responses in chronic liver diseases. Brit. med. J., 1, 527-530.

58) Strelkauskas, A.J., Callery, R.T., McDowell, J., Borel, Y. \& Schlossman, S.F. (1978) Direct evidence for loss of human suppressor cells during active autoimmune disease. Proc. nat. Acad. Sci. USA, 75, 5150-5154.

59) Tage-Jensen, U., Arnold, W., Dietrichson, O., Hardt, F., Hopf, U, Meyer zum Büschenfelde, K.H. \& Nielsen, J.O. (1977) Liver-cell membrane autoantibody specific for inflammatory liver diseases. Brit. med. J., 1, 206-208.

60) Thomas, H.C., Freni, M., Sanchez-Tapias, J., DeVilliers, D., Jain, S. \& Scherlock, S. (1976) Peripheral blood lymphocyte populations in chronic liver disease. Clin. exp. Immunol., 26, 222-227.

61) Tobias, H., Safran, A.P. \& Schaffner, F. (1967) Lymphocyte stimulation and chronic liver disease. Lancet, 1, 193-195.

62) Toh, B.H., Roberts-Thomson, I.C., Mathews, J.D., Whittingham, S. \& Mackay, I.R. (1973) Depression of cell-mediated immunity in old age and the immunopathic diseases, lupus erythematosus, chronic hepatitis and rheumatoid arthritis. Clin. exp. Immunol., 14, 193-202.

63) Vergani, G.M., Vergani, D., Jenkins, P.J., Postmann, B., Mowat, A.P., Eddleston, A.L.W.F. \& Williams, R. (1979) Lymphocyte cytotoxicity to autologous hepatocytes in HBsAg-negative chronic active hepatitis. Clin. exp. Immunol., 38, 16-21.

64) Vyas, G.N. \& Shulman, N.R. (1970) Hemagglutination assay for antigen and antibody associated with viral hepatitis. Science, 170, 332-333.

65) Wands, J.R. \& Isselbacher, K.J. (1975) Lymphocyte cytotoxicity to autologous liver cells in chronic active hepatitis. Proc. nat. Acad. Sci. USA, 72, 1301-1303.

66) Wands, J.R., Perrotto, J.L., Alpert, E. \& Isselbacher, K.J. (1975) Cell-mediated immunity in acute and chronic hepatitis. J. clin. Invest., 55, 921-929.

67) Williams, R.C., Jr., Strickland, R.G. \& Montaxo, J.D. (1980) Subpopulation of T cells $(\mathrm{Tr}$ and $\mathrm{T} \mu$ ) in patients with chronic liver disease. Clin. Immunol. Immunopath., 15, 616-621.

68) Yata, J. (1977) Estimation of helper and suppressor effects of human $T$ cells on in vitro mitogen induced B cell differentiation. Jpn. J. Allergol., 26, 17-19. (in Japanese with English Abstract) 